\title{
국제개발협력과 한국의 사회적 기업
}

\author{
김 동 훈 ${ }^{1)}$ 아시안브릿지 ${ }^{2)}$ 전문위원
}

\section{I. 들어가는 글}

2007년 ‘사회적 기업 육성법’이 제정된 이후 노동부가 8차례에 걸쳐 인증한 국내의 사회적 기업은 2007년 10월 36개소를 시작으로 2009년 7월 현재 251개에 이르고 있다. 노동부의 기준을 충족시 키지 못해 인증을 받지 못한 기업까지 합친다면 515 개의 기관이 지난 2 년 사이에 사회적 기업을 신 청한 것으로 나타나 ${ }^{3)}$ 계속해서 커지는 국내의 사회적 기업에 대한 관심을 반영하고 있다고 할 수 있다. 현재도 노동부의 사회적 기업과 보건복지가족부의 사회서비스기업 지원을 통해 다양한 형태 의 사회적 기업들이 창업되거나 확장되고 있으며 사회적 기업가들을 양성하기 위한 프로그램들도 속속 개설되고 있다. 기업적 접근방식을 통해 사회문제를 해결하려는 사회적 기업은 국내에서는 실 업문제 해결의 대안으로 각광을 받으면서 전폭적인 관심과 지원을 받고 있다고 할 수 있다. 그러나 국내의 사회적 기업 지원책들은 경제위기로 인한 취약계층 보호와 실업문제로 인한 고용창출 효과 등 주로 국내문제에 한정한 사회서비스부문에 집중되어 있어 아직까지는 사회적 기업을 국제개발 협력과 연관 짓는 경우는 거의 없는 것으로 보인다. 반면에 한국에 소개되는 해외의 모범적인 사회 적 기업의 사례들은 자국 내의 고용창출과 취약계층 보호사업을 넘어서 빈곤, 환경, 인권 등 국제개 발협력에서 다루는 글로벌 이슈들을 정면으로 다루는 경우들을 많이 볼 수 있다.

한국에서 '국제개발형 사회적 기업’4)으로 분류할 수 있는 단체들은 많지 않으며 여전히 국제개발협

1) 성균관대 철학과 졸업. 동국대 대학원 사회복지학 석사과정. 조계종사회복지재단·지구촌공생회·한국JTS에서 국제개발협 력사업을 진행했다. 현재 국제개발협력을 위한 사회적 기업 준비그룹인 '아시안브릿지 착한여행사'의 전문위원과 '국제개 발아카데미'의 대표를 맡고 있다. 또한 '개발대안(Development Alternative)'에 대한 블로그를 운영하고 있다. blog.naver. com/xtopaz

2) 舊 아시아NGO센터, 2003년 2월 녹색연합, 아름다운재단, YMCA 등 한국의 시민사회단체들이 공동출자하여 한국과 아시 아 시민사회간의 국제연대를 촉진하기 위해 필리핀 마닐라에 설립한 네트워크 NGO. 2009년 현재까지 약 1,200 여명의 국 내 청소년, 대학생,기업,지자체,시민사회활동가들을 대상으로 장단기 해외연수프로그램을 진행하였다. 2008년 4월에 첫 해외지사인 한국사무소를 서울에 설치하면서 아시안브릿지(Asianbridge)라는 명칭을 사용하기 시작하였다. 한국사무소에 서는 브릿지리더십프로그램, 다문화·이주민브릿지 프로그램, 생태·문화브릿지프로그램 등을 통해 대안적 시민운동프로그 램들을 실험하고 있다. 대표:윤장현(한국YMCA전국연맹 이사장). 홈페이지:www.asianbridge.asia

3) 사회적기업연구원. 2009년. 『2009 사회적기업 개요집』e-book.

http://www.rise.or.kr/ebook/geyo09/viewer_frame.html

4) 사업범위를 국내에 한정짓지 않고 국제개발협력 관련 사업을 시행하고 있는 사회적기업들을 분류하기 위해 '국제개발형 사회적기업'라는 범주를 임의로 사용하고자 한다. 
력은 공적개발원조 (Offical Development Development, ODA)기관들과 개발NGO들의 영역이라 고 할 수 있다. 그러나 2000년대 들어 시민사회단체들의 국제연대사업이 활성화되고 일부단체들 은 공정무역운동에 뛰어들면서 국내에서도 첫 번째 국제개발형 사회적 기업이라고 부를만한 새로 운 영역이 나타나기 시작하였다. 근래 청년들의 국제개발협력사업에 대한 관심이 증가하고, 공정 무역과 같은 대안적인 접근방식들이 보편화되고, 사회적 기업들에 대한 지원이 본격화되며, 개발 $\mathrm{NGO}$ 들의 국제개발협력과 시민사회단체들의 국제연대사업의 경계가 허물어져 가는 등 일련의 상황 은 국제개발형 사회적 기업들에 대한 새로운 논의와 실험을 할 수 있는 조건들이 될 수 있다고 판단 된다. 따라서 이 글에서는 글로벌이슈의 해결을 위해 국제개발협력과 사회적 기업이 어떻게 연계될 수 있으며 앞으로의 바람직한 방향은 무엇인지에 대해 시론적 논의를 해보고자 한다.

\section{II. 사회적 기업 이해하기}

\section{1. 사회적 기업의 특징}

대표적인 사회적 기업 지원기관인 아쇼카재단(Ashoka Foundation)의 의 빌 드레이튼(Bill Drayton) 은 아래와 같이 사회적 기업이 기존의 자선기관이나 원조단체들과 어떻게 다른 접근방식을 취하고 있는지 설명하고 있다.

“우리의 일은 물고기를 주거나 물고기 낚는 법을 가르치는 것이 아니고 새롭고 발전된 어 업을 창조해내는 것이다.”6)

아쇼카 재단 $\mathrm{CEO}$ 빌 드레이튼

사회적 기업가(Social Entrepreneur)들은 서비스의 전달이나 기술이전을 넘어서 새로운 규칙을 창 조하여 문제를 해결하고자 한다. 새로운 규칙을 창조하는 것을 마이크로소프트(MS)의 빌 게이츠 (Bill Gates)는 '창조적 자본주의')라는 개념을 통해 설명하였다. 그것은 시장의 힘이 적용되는 영 역을 현재 시장에서 소외된 계층에까지 확대함으로써 불평등이 해소되도록 하자는 제안이었는데, 그 방법 중의 하나가 기업이 저소득 계층에 맞춰 제품과 서비스를 개발하는 것이었다. 한 가지 사례

5) 아쇼카재단 www.ashoka.org

6) "Our job is not to give people fish, it's not to teach them how to fish, it's to build new and better fishing industries." Bill Drayton. Ashoka Foundation. www. ashoka.org

7) "창조적 자본주의 Creative Capitalism". 빌 게이츠가 2007년 7월 하버드대 졸업식 연설과 2008년 1월 다보스 세계경제포 럼의 '21세기 자본주의의 새로운 접근(A New Approach to Capitalism in the 21st Century)'이란 연설을 통해 주창한 개념 으로, 기업들이 가난한 사람들을 위해 제품과 서비스를 만드는 사업을 창출해야 하며 이런 사업들을 통해 수익을 올리면서 도 시장으로부터 충분한 혜택을 받지 못하는 사람들의 삶을 개선시켜야 한다고 강조한데서 비롯되었다. 
로 대표적 사회적 기업인 그라민은행(Grameen Bank)의 그라민폰(Grameenphone)을 들 수 있다.

그라민은행은 노르웨이의 이동통신회사 Telenor와 손잡고 1997년부터 방글라데시 내에서의 무 선통신사업권을 획득하여 그라민폰이라는 이동통신사업을 시작하였다. 현재 그라민폰은 방글라데 시 최대의 이동통신사로 성장하여 가입자만 1,700 만명을 넘고 있는데 주목해야 할 것은 Village Phone Direct라는 프로그램이다. 이 프로그램은 폰레이디(Phone lady)라고 불리는 휴대전화 아줌 마들이 통신서비스에서 소외되어 있는 저소득계층을 도우면서 자신들의 일자리를 창출할 수 있게 돕는 프로그램이다. 폰레이디들은 그라민 은행을 통해 대출받은 돈으로 휴대전화를 구입하고, 자 신의 휴대전화를 가지고 농촌으로 돌아가 마을 사람들에게 ‘공중 휴대전화’로 제공하여 이용시간에 따라 요금을 받는 사업을 하고 있다. 현재 휴대전화 아줌마들은 전체 가입자 수의 약 $3 \%$ 에 불과하 지만 서비스 이용 매출에서는 전체의 $19 \%$ 에 기여하고 있다.

위의 사례와 같이 사회적 기업가들은 최하위계층(Bottom of Pyramid, BOP)을 더 이상 수혜자나 클라이언트가 아니라 우리와 동등하게 시장에서 활동할 수 있는 생산자이자 소비자라고 생각하며, 이들을 대상으로 한 상품을 개발하고 이들이 생산자로 조직화 할 수 있는 사업을 개발하여 삶의 조 건들을 개선시켜나가고 있다. 또한 개선의 방법으로 기존 시장을 뛰어넘는 새로운 시장을 창출하는 개척자의 길을 걸어감으로써 전체 산업계의 판도를 변화시키는 역할까지도 수행하고 있다.

\section{2. 사회적 기업의 정의}

성공한 사회적 기업가들이 미치는 거대한 사회적 영향력에도 불구하고 새로운 규칙을 추구하는 사 회적 기업가들의 특성으로 인해 ‘사회적 기업이 무엇인가?’에 대해 정의내리기는 더욱 힘들어진다. 정해진 길을 가는 것이 아니어서 사회적 기업가가 생각하고 실천하는 내용에 따라 사회적 기업의 정의가 달라질 수 있고, 사회적 기업들이 처한 지역적, 시대적 맥락도 개념의 정의에 영향을 미칠 수 있기 때문이다. 실제로 사회적 기업이라는 단어를 들으면 유럽에서는 공동체에 기반한 협동조합 운동을 먼저 연상하고, 미국에서는 기업가정신에 기반하여 창의적인 방식으로 사회문제해결에 뛰 어든 개인 기업가들을 연상하며, 한국에서는 실업문제를 해결하기 위한 사회서비스 산업을 연상하 는 등 2009년 현재 시점에서도 사회적 기업은 각자의 역사적 배경과 사회적 맥락에 따라서 여전히 진화하고 있는 단어라고 할 수 있다. 따라서 결론적으로 아직까지 세계적으로 통용되는 사회적 기 업에 대한 명확한 정의나 규범은 존재하지 않는다고 할 수 있다.

8) 그라민은행 www.grameen-info.org 
그럼에도 불구하고 논의의 진전을 위해서 몇 가지 사회적 기업에 대한 통상적 정의를 소개하고자 한다.

“시스템의 변화를 위해 시장기반의 접근방법을 사용하여 사회문제와 시장실패의 문제를 해 결하면서도 사회적 가치를 창출하는 새로운 기회를 잡아내는 혁신적이면서도 지속가능한 접근 방식"9)

“사회적 목적의 서비스나 상품들을 거래하는 사회적 목적을 달성하기 위해 움직이는 조직”

“사회적 목적을 추구하고 이를 위해 수익창출 등 영업활동을 수행하는 조직” ${ }^{11}$

사회적 기업을 범주화 하는 중심적인 기준을 어떤 이는 영리활동을 수행하는 기업적 형태에 초점 을 두는가 하면, 기업적 접근방식에 기초한 사회적 목적에 초점을 두는 사람도 있고, 넓게는 사회적 부를 증진시키는 모든 효율적인 활동을 포함시키는 사람들까지 다양한 스펙트럼을 보이고 있다.

\section{3. 사회적 기업의 분류}

사회적 기업가들의 공통적인 특성을 연구한 '세상을 바꾼 비이성적인 사람들의 힘(The Power of Unreasonable People) ${ }^{12)}$ 에서는 조직구조에 따라 다음과 같이 사회적 기업들을 세 가지 범주로 분 류하여 이해를 돕고 있다. ${ }^{13)}$

첫째, 차입자본 비영리(leveraged nonprofit) 유형이 있다. 정부가 공공재를 공급할 가능성이 없고 민간은 수익성 문제로 참여하려 하지 않는 곳에 참여하여, 모든 종류의 자원 즉 지역민의 자생력, 사회적 자본, 정부의 보조금, 민간의 기부금 등을 지렛대(leverage)로 사용하여 사회변화를 가져오 며 수익자로 하여금 주도권을 쥐게 함으로써 변화의 지속가능성을 담보하려는 기관들이다.

9) "Innovative and sustainable approach to systemic change that uses market based approaches to resolve social problems and market failures and grasp new opportunities to create social value", Kim Alter(Skoll Centre for Social Entrepreneurship), "The introduction of social enterprise and its entrepreneurs", Asian Social Entrepreneurs Summit 2008, Seoul, Oct 2008, 함께일하는재단

10) "social mission driven organizations which trade in goods or services for a social purpose", http://en.wikipedia.org/ wiki/Social_enterprise

11) 노동부 사회적 기업 홈페이지 http://www.socialenterprise.or.kr/company/company01.php

12) 존엘킹턴, 파멜라 하티건. 2008. 『세상을 바꾼 비이성적인 사람들의 힘』. 에이지 21

13) 전게서. pp63 97 
둘째, 혼합형 비영리(Hybrid nonprofit) 유형이 있다. 가장 많은 사회적 기업들이 추구하는 유형으 로 비영리성과 수익이 생기는 이윤추구 전략을 창의적으로 혼합함으로써 새로운 형태의 동력을 만 들어내고 있다. 소외계층을 위한 상품과 서비스 판매에서 수익창출과 재투자를 하면서도 소비자들 의 폭넓은 수요에 대응하고 회사의 지속성을 확보하기 위해 공적, 사적 기부와 자본금들을 영입한다.

셋째, 사회적 벤처기업(Social Business) 유형이 있다. 사회적 미션의 수행을 목적으로 하지만 처 음부터 이윤추구 조직으로써 설립된다. 이 범주의 사회적 기업들은 양적으로는 많지는 않지만 시장 을 기반으로 활동하여 금전적 수익을 사회적 수익으로 연결시켜 사회변화를 창출하는 조직들로 기 업으로서의 정체성이 강하다고 할 수 있다.

다양한 사회적 기업에의 정의와 범주는 사회적 기업의 불확실성을 보여준다기보다는 사회적 기업 의 가능성을 보여준다고 하는 것이 맞을 것이다. 사회적 기업내의 다양성의 존재는 우리로 하여금 특정 사회적 미션을 위해 새로운 창업을 시도하는 방법에서부터, 기존 기업을 사회적 목적으로 전 환시키는 방법, 기존의 비영리조직에 기업적 접근방식을 도입하는 방법, 기존의 조직에서 사회적 기업을 분리시키는 방법 등 다양한 사회문제만큼이나 가장 효율적인 해결방법을 찾는 새로운 기회 를 보여주는 것이기 때문이다.

\section{4. 사회적 기업의 의미}

그렇다면 새로운 기회를 보여줄 수 있는 사회적 기업이 국제개발협력에는 어떤 의미를 줄 수 있는 지 잠시 살펴보자.

“오늘날 세계의 상황은 일류기업이 새로운 시장기회를 발견했을 때의 성장속도와 같은 속 도로 시민부문도 확장될 것을 요구합니다. 자금을 적재적소에 배치하는 효율성과 전 세계 에 번지는 확장성 있는 시민부문이 존재하지 않는다면 세계의 가난문제에 수십억 달러를 쏟아 붓는다 해도 아무 소용이 없습니다. 이것이 되지 않는 한 우리는 결코 가난을 지나간 역사의 일로 만들지 못합니다.”14)

룸투리드(Room to Read) 설립자 존 우드(John Wood $)^{15)}$

14) 전게서. $\mathrm{pp} 232 \sim 233$.

15) 마이크로소프트사의 임원이었던 존 우드는 네팔에서 휴가기간을 보내다가 산간오지지역 학교들의 열악한 교육환경을 목 격하고 룸투리드를 설립하게 된다. 2000년에 활동을 개시한 이래 2009년 현재까지 전 세계에 약 7,000여개이상의 도서 관을 통해 300 만 명 이상의 어린이들을 위한 교육환경을 개선하였다. 한국에서는 <히말라야의 도서관>이란 번역서가 소 개되어 있다. (www.roomtoread.org) 
글로벌 이슈들을 해결하려는 대안이나 조직들은 해당이슈들이 가지는 역동성과 상호연계성 그리고 확산되는 속도 등을 고려했을 때, 존 우드의 지적처럼 시장기회를 포착한 기업들의 성장속도만큼이 나 효율적이면서도 확장성 있는 체계를 가졌을 때 유의미한 결과를 만들어낼 확률이 크다. 한국의 $\mathrm{ODA}$ 기관들이나 개발 $\mathrm{NGO}$ 들이 우수사업의 경험과 성공모델을 가지고 있다 하더라도 다른 지역이 나 기관으로 신속하게 전파되거나 적용되지 못할 경우가 있다. 이러한 상황은 좋은 모델도 빈곤에 대한 효과적인 공세가 되지 못함으로써 전반적인 시스템 개선에 기여한다기보다는 자기기관의 활 동크기 만큼만 효과를 보는 ‘그들만의 리그’가 되기 쉽다. 그러나 사회적 기업들은 서비스의 실적, 시장에서의 매출 또는 자본의 유치 등을 통해 자신들의 상품과 서비스가 얼마나 사회적 변화를 확 산하는지 직접적이면서도 명확하게 피드백을 받기 때문에 기존의 비영리조직들에 비해서 효율성이 나 확장성을 중시할 수밖에 없다. 이러한 사회적 기업들의 접근방식은 국제개발협력에 있어서 효과 성을 더하는 추진력이 될 수 있을 것이다.

빈곤퇴치 문제에 있어 국제기구들과 정부기구들은 너무 큰 정책과 담론들을 다루고 있고, 비영리기 관들은 너무 협소한 현장을 다룸으로써 각각의 단점을 가지고 있기 마련이다. 또한 각각의 기관들 은 자신들의 이해관계로 인해 서로 연대하고 소통하는데 일정정도 어려움을 겪고 있다. 이러한 서 로의 차이와 단점들을 해결하고자 근래에 글로벌 파트너십이나 원조효과성 또는 원조조화의 문제 가 진지하게 다루어지고 있기도 하는데 사회적 기업들이 여기에 새로운 자극제가 될 수 있을 것이 다. 사회적 기업들은 작은 현장을 기반으로 하지만 시장의 확장성만큼이나 넓은 수준의 파급력을 성공기준으로 삼고 있으며, 시장확대나 사회적자본의 증대를 위해서는 모든 이해관계에 적극적으 로 연동하기 때문이다. 국제개발협력분야에 빈곤퇴치를 위한 가장 적극적인 주체가 등장하고 있는 것이다.

\section{III. 사회적 기업으로 국제개발하기}

\section{1. 해외의 사회적 기업들}

사회적 기업들은 $\mathrm{BoP}$ 계층을 구매력이 없는 계층이나 도움을 받아야 하는 수혜자로 보는 것이 아니 라 시장의 주체인 생산자이면서 고객으로 바라봄으로 해서 새로운 해결책을 제시하고 있다고 할 수 있다. One World Health(이하 OWH $)^{16)}$ 도 그러한 예로서, 가난한 환자들이 많은 저개발국의 풍토 병 치료제를 개발하는 것을 목적으로 설립된 제약회사이다.

16) Institute for One World Health(iOWH) (www.oneworldhealth.org) 
“OWH는 2000년 제약연구원 빅토리아 헤일이 세웠다. 그는 제약 본연의 의무는 경제성을 넘어서 생명을 구하는 것이라고 생각했다. 헤일이 주목한 질병은 ‘리슈마니아 편모충증’이 었다. 인도 · 네팔 · 방글라데시 · 브라질 등에서 연간 20만 명이 이 질병으로 사망하고 있 다. OWH의 홍보담당 버니사 샌커러는 “헤일은 이미 1960년대에 이 질병에 효과적인 치료 약이 개발됐다는 것을 알았다" 며 “문제는 경제성 때문에 이 약품이 시판되지 않았다는 것 이다. 그것은 비극이었다.”고 말했다. (중략) 2004년, 2 년에 걸쳐 역대 최대 규모로 3상 임 상실험을 시행한 결과 약이 나왔다. 21일만 투약하면 $95 \%$ 의 환자들이 완치됐다. 기적이었 다. 샌커러는 “우리가 개발한 약품이 첫 번째 치료제는 아니었지만, 가장 저렴한 약품이라 는 게 중요하다"며 기존 약품은 175 달러(약 20만원)가량이지만, 우리 약품은 10 달러면 충 분하다”고 말했다. 인도 정부는 2006년 말 이 약품을 승인했다. OWH는 빠른 생산과 보급 을 위해 인도의 제약업체에 아예 특허권을 넘겼다. 업체가 원가에 약품을 공급하는 조건으로." ${ }^{17)}$

OWH는 저개발국가 환자들은 원조만으로는 감당할 수 없으며 오히려 빈곤층의 구매력에 맞출 수 있는 저가의 약품을 공급한다면 효율적인 질병퇴치의 길을 열 수 있을 것으로 보아 투자자들을 유 치하여 상업화를 포기한 약품들(Orphan Drugs)의 권리를 이전받아 약품을 개발하였다. 헌신적 연 구자를 모아 약을 개발한 후 제조법을 현지 공장에 무상 이전하는 방식으로 가격을 낮추었으며 수 면병, 설사병, 말라리아 치료제도 이런 방식으로 개발하고 있다.

One World Health 이외에도 해외에서는 사회적 기업으로 국제개발협력에 참여하는 기관들을 어렵 지 않게 찾을 수 있다. 2003년도에 타임지가 Time Heroes에 선정하였고, 뉴스위크가 세계를 바꿀 10 대 발명품으로 선정한 폐달형 소형관 개펌프(Money Maker)를 개발한 킥스타트(Kick Start) ${ }^{18)}$ 도 그러한 예이다.

“이 기업의 야심찬 목표는 기업의 성장을 자극함으로써 부의 양극화를 해소하고 그 결과 아프리카에 중산층을 형성하는 것이다. (중략) 킥스타트는 수익성 있는 소규모기업을 설립 하려는 현지 사업가들이 구입하여 사용할 수 있는 저비용신기술을 개발하고 촉진함으로써 새로운 기업과 일자리를 창출한다. ${ }^{19) "}$

“킥스타트는 제품마다 엄격한 기준을 적용한다. 특히 가격이 적정하고, 수동으로 작동되

17) 한겨레 21(770호): "이 멋진 기술”. 2009.7.24.

18) 킥스타트(KickStart) www.kickstart.org

19) 존엘킹턴, 파멜라 하티건. 2008. 『세상을 바꾼 비이성적인 사람들의 힘』.p152. 에이지 21 
며, 에너지 효율이 높고, 자전거나 버스로도 운반할 수 있으며, 내구성이 있어야 한다. 또 한 최소한의 훈련으로도 제품을 설치하고 사용할 수 있어야 하고, 유지보수가 아주 쉬워야 만 한다. ${ }^{20) ”}$

킥스타트가 머니메이커(Super Money Maker Pressure Pump)라는 발로 밟아서 작동하는 관개 펌프를 내놓기 전까지 아프리카 케냐의 농민들은 하루 종일 양동이로 물을 길어와야 했다. 그러나 저렴한 가격의 머니메이커를 구입한 농민들은 물을 끌어들이는데 쓰던 시간을 줄이고 작물 재배에 더 집중하였고 수확량이 증가하는 결과를 맞게 되었다. 특히 건기에도 농사를 지속할 수 있음으로 해서 10 배 이상의 소득증진 효과를 가져오게 된다. 2009년 초까지 머니메이커는 129,000 개가 판 매되었고 킥스타트의 기술로 인해 농민들은 자급형 농가에서 벗어나 82,900개의 자영농가와 소기 업들로 재탄생 되었다. 이들은 매년 8천3백8십만 달러의 이익과 임금을 창출하고 있으며 이로 인해 414,000 명의 주민들이 빈곤선에서 벗어난 것으로 집계되고 있다. 킥스타트로 인해 발생한 경제효 과는 케냐에서만 $\mathrm{GDP}$ 의 $0.6 \%$, 탄자니아 GDP의 $0.25 \%$ 해당된다고 추정된다. 킥스타트는 기부자 들이 자신들의 회사에 1 달러를 투자하면 15 달러의 생산유발효과를 가져오며, 자신들의 기술을 활 용한 아프리카에서의 1 인당 빈곤퇴치 비용을 아래표와 같이 약 $\$ 60$ 로 계산하고 있다.

\begin{tabular}{|c|c|c|}
\hline & 무상보급 & 킥스타트 \\
\hline 기부금 & $\$ 2,000,000$ & $\$ 2,000,000$ \\
\hline 펌프당 비용 & $\begin{array}{l}\text { - 생산비 } \$ 65 \\
\text { - 분배비용 } \$ 85 \\
\text { - 행정비용 } \$ 140 \\
\text { 합계 : } \$ 290\end{array}$ & $\begin{array}{l}\text { - 생산비 } \$ 65 \\
\text { - 판매영업 } \$ 124 \\
\text { - 행정비용 } \$ 140 \\
\text { - (판매수익) }-\$ 72 \\
\quad \text { 합계 : } \$ 257\end{array}$ \\
\hline 분배개수 & 6,897개 & 7,782개 \\
\hline 사업창출비중 & 30\%(2,069개) & $80 \%(6,226$ 개 $)$ \\
\hline 펌프당 연간 평균소득 & $\$ 1,100$ & $\$ 1,100$ \\
\hline 4년간 전체 소득효과 & $\$ 9,103,600$ & $\$ 27,394,400$ \\
\hline 빈곤선극복인구 & 10,345 명 & 31,130명 \\
\hline 1인당빈곤퇴치비용 & $\$ 193$ & $\$ 64$ \\
\hline
\end{tabular}

출처 : http://www.kickstart.org/what-we-do/why-we-sell/

20) 전게서.p222. 
킥스타트와 같은 기업들의 영향력이 얼마나 큰 것인지를 확인할 수 있는 곳으로는 전 지구적인 수 준의 사회적 기업 지원사업을 펼치고 있는 아쇼카재단(Ashoka Foundation)을 들 수 있다. 아쇼 카재단은 1981년 빌 드레이튼에 의해 설립된 조직으로 사회를 변혁할 가능성이 있는 선구적인 사 업을 선정하여 투자하는 사회적 기업이다. 사회적 기업의 개념을 처음 인식시킨 것도 이들이었 으며 세계적 수준에서 유망한 사회적 기업가를 발굴하여 지원하는 독보적인 시스템으로 유명하 다. 1981년 인도에서 긴급전화상담센터 차일드라인(Childline)을 설립한 제루 빌리모리아(Jeroo Billimoria)를 첫 번째 아쇼카펠로우(Ashoka Fellow)로 선정한 이래 지금까지 60여 개 국에서 사 회적 기업가 2,000 명을 발굴해 지원하고 있다.

“J.B. 슈럼이나 메리 고든을 포함한 약 1,600명(2005년 기준)의 아쇼카 연구원이 만들어 낸 실현 가능한 사업 모델의 $93 \%$ 는 대규모로 보급되어 사회를 변화시키는 원동력이 되고 있다. 더욱 놀라운 것은 연구원들이 만들어낸 사업모델의 약 $56 \%$ 가 5 년 내 각국 정책에 어 떤 형태로든 영향을 미치며, $71 \%$ 는 10년 이내에 경직된 정책의 변경이나 폐지를 촉발시킨 다는 것이다. "21)

재단에 의해 선정된 아쇼카 펠로우들은 3년 간의 급여를 지원받는 것 외에도 세계적 수준의 컨설팅 회사인 맥킨지(McKinsey\&Company)와 홍보회사인 힐앤놀튼(Hill\&Knowlton) 그리고 비영리기 관인 ILSP(International Senior Lawyers Project)로부터 무상의 자문서비스를 제공받을 수 있다. 그리고 무엇보다 전 세계에 걸쳐있는 아쇼카 펠로우들의 네트워크 안에 들어감으로써 이들의 축적 된 경험과 지식, 인맥을 최대한 활용할 수 있는 것이 장점이다. 현재 아쇼카재단은 세계 25 개국에 지부를 두고 있으며 160 명의 활동가가 상근하고 있다.

국제개발형 사회적 기업들에 대한 이해를 돕고자 주로 성공한 사회적 기업들의 개별사례를 중심으 로 소개하였다. 그러나 실제로 창업되는 많은 사회적 기업들은 새로운 길을 개척하는 만큼 생존을 위한 냉혹한 싸움을 통해 명멸을 반복하고 있다. 새로운 시도들인 만큼 아직은 성공을 뒷받침할만 한 사회적 지지대가 충분하지 않다고 할 수 있는데, 최근의 서구사회에서의 사회적 기업을 둘러싼 지형변화는 긍정적이라고 할 수 있다. 사회적 기업들에 대한 정부차원의 지원방안들이 만들어지고 있으며, 사회적 기업들을 지원하기 위한 사회적 금융기관들이 설립되고 있고, 기존의 공익재단들이 자선기부에서 사회적 투자로 사업을 전환하며, 주요대학들이 사회적 기업을 교과목으로 채택하는 등 사회적 기업들의 출현과 성공을 용이하게 하기 위한 여러 조건들이 형성되어 가고 있다. 이러한 변화들은 국내에서의 사회적 기업에 대한 관심의 증가와 함께 앞으로 한국사회에도 적잖은 영향을

21) 와타나베 나나. 2007.『체인지메이커』. 넥서스BOOKS. p24 
미칠 것으로 예상되어 한국의 국제개발협력 관련자들도 지속적인 모니터링을 통해 적극적으로 활 용해나간다면 좋을 것이다.

\section{2. 한국의 사회적 기업들}

국내의 사회적 기업들 중 국제개발협력사업과 관련된 단체들은 많지 않으며 관련기업이라 하더라 도 해외의 사례들과 같이 다양하지 않다. 노동부와 보건복지가족부의 사회적 기업지원 사업들은 어 디까지나 국내의 취약계층보호를 중심으로 이루어지기 때문에 국제개발 관련 사업만으로 사회적 기업인증을 받고 지원을 받는 경우는 없다. 따라서 창업을 위한 외부지원이 거의 없는 상황에서 특 별한 변화가 없는 이상 국제개발형 사회적 기업들이 자리를 잡는 데에는 좀 더 많은 시간을 필요로 할 것으로 예상된다. 국내에서는 공정무역단체들이 2000년대 초반부터 창업하여 지금은 일정정도 시장진입에 성공하여 국제개발형 사회적 기업의 다수를 이루고 있으며, 그 외에는 최근 2 3년 사 이에 성장하고 있는 대안여행 관련단체들이 부각되고 있다.

\section{가. 공정무역단체들}

공정무역은 국제무역에서의 공정성을 확보하려는 운동으로 저개발국가의 생산자들에게 공정한 노 동의 대가를 지불해 그들의 삶을 나아지게 하자는 사회운동이다. 세계시장에서의 경쟁에서 뒤쳐질 수밖에 없는 저개발국가의 생산자들을 위해 공정무역단체들이 더 나은 무역 조건들을 제공하여 자 립능력을 높여줌으로써 지속가능한 발전을 도모하는 운동이다. 공정무역운동이 보여주는 지향점은 사실상 국제개발협력이 다루는 가치들의 총집합이라고 해도 과언이 아니다.

“공정무역은 기존의 자유무역과는 다른 지향을 가진다. 그 지향들은 다음과 같다. 지역적 맥락에서의 공정한 임금 지급, 피고용자에게 향상의 기회제공, 경제적으로 소외받고 있는 사람들에게 우선적으로 일자리 제공, 특히 경제적 소외가 심한 장애인들에게 평등한 고용 기회 제공, 환경적으로 지속가능한 실천, 공적 투명성, 장기간의 무역체계 구축, 지역 맥락 내에서의 건강하고 안전한 노동 조건 제공, 생산자에 대한 재정적·기술적 지원, 고용과 월급에 있어 남녀동등 대우, 주문과 동시 대금 선지급을 통한 생산자 단체에 대한 안정적인 재정지원, 어린이 노동 반대 등등”22)

한국에서는 시민사회단체들이 국제연대사업의 과정에서 세계시민으로서의 책임을 통감하고 국제사 회에 기여하는 실천적인 방법들을 고민하는 과정에서 공정무역이 시작되었다고 할 수 있다. 한국공

22) 김정희. 2009. 『공정무역, 희망무역』. p16 17. 동연. 
정무역의 시작은 2000 년대 초로 거슬러 올라가는데 2003년 9월에 아름다운 가게 ${ }^{23)}$ 가 최초로 아시 아지역에서 수입한 수공예품들을 '대안무역’이름으로 국내에 판매하기 시작한 것이 처음이라 할 수 있다. 2004년 들어 두레생협연합회는 전담조직인 에이피넷(APNet) ${ }^{24)}$ 을 설립하여 '민중교역'이라 는 명칭으로 필리핀의 마스코바(Mascovado)도 설탕을 수입판매하기 시작하여 나중에는 올리브유 수입으로까지 확대하였다. 2005년에는 한국YMCA전국연맹이 동티모르 커피를 통한 공정무역사업 을 시작하여 2007년부터는 청소년들에게 직업훈련과 창업의 기회를 제공하는 공정무역 커피숍 까 페티모르(Cafe Timor) ${ }^{25}$ 를 개설해오고 있다. 연해주 고려인 정착지원사업을 하던 동북아평화연 대는 2005 년에 (주)바리의꿈 ${ }^{26)}$ 을 설립하여 고려인들의 자활을 돕는 먹거리 사업을 시작하여 2007 년 연말에는 월매출이 1억 원에 이르기도 하였다. 여성환경연대는 2006년 11월부터 ‘희망무역'이 라는 이름으로 저개발국가의 여성생산자들을 돕기 위해 일본 공정무역단체 네팔리바자로(Nepali Vazaro)를 통해 의류 및 생활용품을 수입판매하기 시작하였는데 2007년 5월에는 전문적인 공정무 역회사인 페어트레이드코리아(Fair trade Korea) ${ }^{27)}$ 로 분가되기에 이르렀다. 2007년 10월에는 전 $\mathrm{EBS} \mathrm{PD}$ 였던 박창순씨가 한국공정무역연합을 설립하여 공정무역캠페인을 벌이는 한편 초콜릿, 축 구공 등의 공정무역상품을 수입판매하기 시작하여 국내 공정무역 운동에서의 개인 창업도 시작되 기에 이르렀다.

한국에서의 공정무역은 윤리적 소비시장이 확장됨에 따라 일부 단체들은 손익분기점을 넘어 흑자 경영을 시작하였으며, 까페티모르, 바리의 꿈, 페어트레이드코리아 등의 공정무역단체들은 노동부 의 사회적 기업 인증을 받고 인력과 컨설팅 지원을 받음으로써 사업을 활성화시켜가고 있다. 공정 무역단체들의 활동범위도 확장되어 공정무역을 주제로 한 국제회의가 국내에서 개최되기도 하고, 공정무역에 관한 연구서와 번역서들이 속속 출간되고 있으며, 2 년마다 열리는 세계공정무역총회 (WFTO)에 한국단체들이 참여하여 외국단체들과 소통하기 시작하였다. 또한 매년 5월 둘째 주 토 요일의 세계 공정무역의 날(World Fair Trade Day ${ }^{28)}$ 에는 국내 단체들간의 연합행사가 열리는 등 공정무역업계의 전반적인 발전이 가속화되고 있다.

한국의 공정무역단체들은 앞으로 일부 상품에 한정되어 있는 공정무역품목을 다양화시켜야 하며, 전체 윤리적 소비시장의 확대를 위한 공동의 애드보커시(Advocacy) 활동을 전개하고, 해외의 공정 무역단체들과 공정무역 연대체들과의 교류협력을 강화하는 한편, 생산자들을 조직하며 품질을 관

\footnotetext{
23) 아름다운가게의 '아름다운커피' www.beautifulcoffee.com

24) 두레생협연합회의 민중교역 'APNet' www.apnet.or.kr

25) 한국YMCA전국연맹의 '피스커피' www.peacecoffee.co.kr

26) 동북아평화연대의 '바리의 꿈' www.baridream.co.kr

27) 페어트레이드코리아 ecofairtradekorea.co.kr

28) 한국공정무역연합 www. fairtradekorea.net
} 
리하는 등의 현장사업능력을 제고해야 하는 등 많은 과제를 가지고 있다. 이러한 국내 공정무역단 체들의 지속적인 성장은 한국의 국제개발협력 분야에서도 다양한 접근방법을 열어주는 중요한 계 기가 될 것이라 예상된다.

\section{나. 대안여행조직들}

대안적 여행은 책임여행(Responsible Travel), 윤리적여행(Ethical Travel), 공정여행(Fair Travel) 등 다양한 명칭으로 불리고 있는데 대중관광(Mass Tourism)의 폐해를 극복하기 위해 대 안적인 여행방식을 도입함으로써 우리의 여행활동이 현지의 경제에 기여하고, 현지의 사회문화에 긍정적인 영향을 미치며, 현지의 환경보존에 기여하는 한편 여행자들이 현지주민들과 더욱 깊게 교 류할 수 있게 하는 모든 대안적 여행활동들의 총칭이라 할 수 있다.

한국에서도 경제위기와 상관없이 연간 해외출국자수가 기본적으로 1천만 명이 넘는 시대가 됨으로 인해, 여행자들의 소비패턴이 책임성 있고 윤리적으로 바뀌었을 경우 관광산업에 의존하는 저개발 국가들에서 대안적 여행은 $\mathrm{ODA}$ 를 통한 원조 이상의 효과를 가져 올 수 있을 것으로 예상되며, 여 행자와 여행지 주민들이 대등한 위치에서 관계를 맺을 수 있는 여행패턴을 만든다면 현장에서의 살 아있는 세계시민교육도 가능하게 된다.

대안적 여행과 국제개발협력과의 관계는 대안여행조직들이 대안여행프로그램을 위해 여행지의 지 역주민들과 어떤 관계를 맺어야 하는지의 기준을 보면 알 수 있다.

(1) 여행사, 소수부족, 현지여행사 등 여행에 관계된 주체들 간의 동등한 협의가 가능해야 한다.

(2) 환경과 사회적 문제, 결산 등에 대해 투명하고 책임감 있는 사업수행을 해야 한다.

(3) 지역주민에게 고용의 기회와 성장의 기회를 주는 일자리를 제공해야 한다.

(4) 지역공동체가 직접 관광프로그램을 운영할 수 있도록 훈련과 개발과정을 도와야 한다.

(5) 관광개발자의 국가에서 적용되는 안전, 건강, 환경 등의 기준과 국제적 규약을 지킨다. ${ }^{29)}$

2009년은 한국의 대안여행단체들에게는 본격적인 대안여행 활동을 시작한 한 해로 기억될 것이다. 2009년 2월과 4월에 해외에 진출한 한국기업 감시운동 등을 펼쳐 온 국제민주연대 ${ }^{30)}$ 가 중국 윈난 성 소수민족마을을 둘러보는 최초의 공정여행 팩키지(Package) 여행프로그램을 선보임으로써 국 내에서도 조직화된 대안여행프로그램이 본격적으로 시작되는 계기를 마련하였다. 6월에는 평화운

29) 이매진피스. 2009.『희망을 여행하라』.p447. 소나무.

30) 국제민주연대 www.khis.or.kr 
동을 해온 이매진피스(Imagine Peace) ${ }^{31}$ 에서 최초의 공정여행 가이드북 “희망을 여행하다” 를 출 간하였다. 7월에는 아시안브릿지(Asian Bridge) 착한여행사가 대안여행을 통한 사회적 기업 창업 을 목표로 최초의 상업적인 착한여행프로그램인 '메콩강시리즈'를 출시하여 베트남, 라오스, 캄보 디아에서의 시범사업을 완료하였다. 8월에는 하자센터의 여행협동조합MAP ${ }^{32)}$ 이 여성들만을 대상 으로 한 네팔 히말라야 트레킹 공정여행상품을 출시하여 특화된 전문 대안여행 코스의 개발을 시작 하였다. 9월 들어서는 사회적 기업벤처 투자회사인 (유)SOPOONG을 중심으로 아시안브릿지, 착한 여행사, 여행협동조합MAP, (주)제주생태관광, (주)이장 등이 컨소시엄을 이루어‘대안적 여행기업 가 양성 아카데미' ${ }^{33)}$ 를 진행하고 있다. 11월 14일까지 계속될 이 프로그램은 노동부와 '함께 일하 는 재단'의 지원으로 여행을 소재로 사회적 기업을 창업하고자 하는 예비 사회적 기업가들을 양성 하고자 하는 프로그램이다.

앞서 언급된 단체들 외에 희망제작소, 한국YMCA전국연맹, 아름다운가게 등 주요 시민사회 단체 들이 현재 독자적인 대안여행기업이나 프로그램을 준비하고 있어 조만간 대안적여행이 공정무역에 뒤이어 한국 국제개발형 사회적 기업의 한 섹터를 이룰 수 있을 것으로 예상된다. 한국의 대안여행 사회적 기업들은 대부분 지난 2 3년 사이에 만들어져 아직 초기단계이다. 따라서 한국에서 여행자 들을 모집하고 기존에 개발되어 있는 해외의 대안적 관광지들을 여행하는 수준에 머무르고 있으나, 사업의 성장에 따라 빈곤지역에서 지역사회조직을 통한 관광개발 프로그램들을 현지파트너들과 직 접 진행함으로써 소득창출과 환경과 문화보전 등이 동시에 어우러지는 지속가능한 개발의 새로운 모델을 정립할 수 있을 것으로 기대한다.

\section{3. 새로운 시도들}

공정무역과 대안여행이 어느 정도 사업규모를 갖추기 시작한 국제개발형 사회적 기업이라면 기존 조직들의 사회적 기업 진입이나 신규조직들의 새로운 창업활동들도 활발해지고 있다.

한국의 대표적인 사회적 기업인 아름다운가게는 기존의 공정무역사업인 '아름다운 커피' 이외에 국 내 재활용사업의 수익금을 적립하여 영국 옥스팜(Oxfam)과 함께 2007년 6월부터 아름다운세상 프로젝트(The Beautiful World Project) ${ }^{34)}$ 를 진행하고 있다. 인도, 네팔, 방글라데시를 통과하는 갠지즈강과 브라마푸트라강 유역의 주민들이 몬순 시기에 겪는 홍수피해를 경감시키기 위해 재해 대피시설, 식수 · 위생시설, 영농기술 전수, 대안기술 이전 등의 인도주의 지원사업과 지역개발사업

\footnotetext{
31) 이매진피스 www.imaginepeace.or.kr

32) 여행협동조합MAP map.haja.net

33) 대안적 여행기업가 양성 아카데미 blog.tour4us.net

34) 아름다운가게의 '아름다운세상프로젝트' world.bstore.org
} 
을 실시하고 있다.

개발NGO인 한국국제기아대책기구는 2008년 2월에 사회적 기업 행복한 나눔을 설립하고 자선가게 운영과 이동바자회, 구호물품지원, 대안무역사업을 진행해오고 있다. 2009년 6월부터 멕시코 치아 파스(Mexico Chiapas)주에서 생산한 커피를 공정무역으로 수입하여 국내에 출시함으로써 기존 자 선가게 수익금의 국제개발협력사업 환원뿐만 아니라 공정무역사업자체를 통한 개발협력사업도 진 행하게 되었다.

경남 산청에 소재한 대안기술센터 ${ }^{35)}$ 는 2006년 5월에 에너지자립과 환경문제, 저개발국가의 지역사 회개발 및 빈곤퇴치 등을 고민하면서 대안기술의 보급과 교육을 위해 설립된 기관으로 재생에너지, 생태건축 등에 대한 워크샵(Workshop)과 캠프(Camp)를 진행하고 있다. 최근에는 소형풍력발전 기, 자전거 인력발전기, 태양열조리기 등을 생산하는 사회적 기업인 에너지팜(Energy Farm)의 창 업을 돕기도 하였다.

에딧더월드(Edit-the-World)는 2009년 3월에 설립된 국제활동 전문 사회적출판사로 사회적, 공 익적으로 유익한 콘텐츠를 발굴, 기획, 출판하는 소셜리싱(Socialishing: Social + Publishing) 운 동을 펼치고 있다. 국제활동과 국제이슈 콘텐츠에 바탕을 둔 '국제활동의 공공재 확충'을 목표로 하 여 국제개발협력사업에 종사하는 관계자들의 경험과 지식들이 우리사회에 하나의 공공재로써 확산 시킬 수 있는 출판을 준비하고 있다. 2009년 9월부터 국제활동 준비총서, 국제활동 지식총서 시리 즈를 발간할 예정이다.

인포뉴스(iNPOnews) ${ }^{36)}$ 는 2009년 5월에‘국제개발협력 전문 인터넷 미디어’를 표방하며 출범한 인 터넷 언론사로 2008년 3월에 설립된 국제개발 협력지원기관 자비은행(Jabi Bank)의 산하기관이 다. 현재 인터넷신문, 뉴스레터, 인포뉴스TV 등을 내보내고 있으며, 국내 최초의 국제개발협력전문 언론사로서 국내외에 객원기자와 특파원들을 두고 국제개발협력과 비영리마케팅에 관한 뉴스들을 전문적으로 보도하고 있다.

이처럼 국내에서도 자선가게, 대안기술, 사회적출판, 미디어 등 다양한 아이템으로 국제개발협력과 사회적 기업을 연계하여 고민하는 활동가들이 늘어나면서 새로운 시도들이 곳곳에서 벌어지고 있 으며 이러한 추세는 앞으로도 계속 될 것으로 보인다.

35) 대안기술센터 www.atcenter.org

36) 인포뉴스 www.inponews.com 


\section{IV. 사회적 기업과 ODA}

\section{1. 사회적 기업과 ODA기관의 파트너십}

사회적 기업의 특징 중 하나는 다양한 재정동원방법을 추구한다는 것이다. 대부분의 사회적 기업들 은 위험을 분산하고 폭넓은 사회적 지지를 확보하며 새로운 자원개발로 연계하기 위해 회사의 영업 이익에서부터 개인후원금, 공공재단 기부금, 정부보조금, 벤처자본 투자금 등 다양한 재정을 통해 서 사업을 유지 · 확장하고 있다. ODA기금 또한 사회적 기업들에게 중요한 자금원의 하나일 수 있 어 여러 방식으로 협력관계가 맺어지고 있다.

“유니세프, WHO, 엑슨모빌, 스미토모 화학, AtoZ사 그리고 어큐먼펀드(Acumen Fund) 까지 비영리 · 영리 단체가 합동으로 성공시킨 벤처 비즈니스가 말라리아 방충 모기장입니 다. 만약 이 비즈니스를 기부만으로 해결하려 했다면 기부금이 바닥이 난 뒤엔 모든 것이 멈춰 버렸을 테죠. "37)

어큐먼펀드 ${ }^{38)}$ 설립자 재클린 노보그라츠(Jacqueline Novogratz)

어큐먼펀드는 재정적 지원이 필요한 기업가를 선정하여 안정적인 규모로 성장시킴으로써 이들이 빈곤층에 필요한 물자나 서비스를 공급하도록 하고 있다. 어큐먼펀드의 성공적인 프로그램 중의 하 나는 탄자니아에서의 말라리아 방충모기장의 개발과 보급이었다. 어큐먼펀드가 투자한 살충모기장 은 6 개월마다 살충제를 분무해야 하는 일반모기장에 비해 살충효과가 5 년 정도 지속되며 가격도 5 불 7불 사이로 저렴한 편이다.

어큐먼은 아프리카에서의 효율적인 말라리아방지를 위해 UNICEF와 WHO와 공동으로 살충모기장 의 원천기술을 보유한 일본의 스미토모화학(Sumitomo Chemical Company)과 원단을 제공할 수 있는 엑슨모빌(Exxonmobil)사를 섭외하였고, 현지 생산을 위해 아프리카 현지기업을 물색하던 중 탄자니아 아루사(Arusha)에 위치한 직물과 플라스틱 생산업체인 ‘AtoZ Textile Mills Limited’를 발굴하여 새로운 모기장을 생산할 수 있도록 신규설비 설치를 위한 사업비를 대출하여 생산에 들 어갔다. 현재 AtoZ사는 매년 7백만 개 이상의 살충모기장을 생산하고 있으며 생산시설을 확대하여 여성들을 위한 2,000 개 이상의 일자리를 창출하였다. 모기장의 대부분은 UNICEF에 의해 구매되

37) 와타나베 나나. 2007.『체인지메이커』. 넥서스BOOKS. p24

38) 어큐먼펀드 www.acumenfund.org 재클린 노보그라츠가 2001년 설립한 사회적벤처 투자회사이다. 안전한 식수개발, 공 중보건위생기술, 주택공급의 세 분야를 중심으로 역량있는 기업가들을 발굴하여 지원한다. 미국 뉴욕에 본사를 두고 있 으며 한국에서는 '블루스웨터'라는 책을 통해 설립자의 활동이 소개되었다. 
어 아프리카 전역에 보급되고 있다.

$\mathrm{ODA}$ 기관들이 사회적 기업들과 공동협력체제를 구축하거나 사회적 기업의 생산품을 구매하는 것 이외에도 독자적으로 지역사회개발의 일환으로 사회적 기업 지원을 위해 프로그램을 운용하는 경 우들도 있다. USAID는 불가리아에서 '지역모금과 사회적 기업 프로그램(CFSE, Community Fund and Social Enterprise Program)'을 2001년부터 5년간 실시하여 불가리아 NGO들의 재정 적인 지속가능성을 제고시킴으로써 개발사업의 효율성을 높이고자 하였다. 이 프로그램은 불가리 아 $\mathrm{NGO}$ 들이 외부의 후원기관들에 의존하기보다 자조능력을 향상시키기를 원하여, 지역사회와 주 민들을 통한 모금역량을 높여줄 수 있는 펀드레이징, 프로젝트 설계와 관리, 회계와 재무 관리 등의 교육프로그램을 제공했으며, $\mathrm{NGO}$ 들이 사회적 미션에 따른 경제활동 수행의 법적 요건을 갖출 수 있도록 지원하였다. ${ }^{39)}$

USAID는 니카라구아(Nicaragua)에서 현지의 공정무역 커피생산자조합을 발굴하여 국제시장에 진 출시키기도 하였다. USAID는 니카라구아의 ‘El Gorrion Coffee Cooperative’가 생산한 1,150헥 타르의 커피를 공정무역커피로 인증 받도록 지원하였고, 조합의 커피는 공정무역라벨의 획득으로 고품질을 공인받게 되어 해외수출이 가능하게 되었다. 세계 공정무역시장으로의 진입은 생산자들 로 하여금 안정된 수입을 보장하여서 개인소득의 증가와 더불어 조합차원에서 지역의 개발프로젝 트를 수행할 수 있는 여유를 만들어 주었다. ${ }^{40)}$

$\mathrm{ODA}$ 기관들로써는 원조효과성을 높일 수 있는 국제개발협력의 파트너로써 사회적 기업들의 활동 을 지원할 필요가 있으며 다음과 같은 방식들을 고려해볼 수 있을 것이다.

첫째, 국내외 국제개발형 사회적 기업들의 재화나 용역을 우선 구매하는 방법이 있다. 서비스 인프 라를 확대하는 프로젝트형 사업을 넘어서 민간의 잠재력을 극대화하기 위한 투자형 지원사업으로 설계해 볼 필요가 있겠다. 프로젝트 수주업체를 선정하는 것처럼 대안기술의 개발이나 특정 사회서 비스의 확대를 위해 현지의 사회적 기업들을 선정하여 협력관계를 맺고 공공시장으로의 역할을 해 줄 수 있을 것이다.

둘째, 사회적 기업들이 현지에서 실행하고 있는 인도주의적 지역개발사업을 보조하는 방법이 있다. 공정무역단체나 대안여행 사회적 기업들은 자신들의 구매액 이외에도 현지의 파트너들인 생산자 공동체들의 숙원사업들을 할 수 있게 추가적인 지원금을 제공하기도 하는데, ODA기관들이 현지단

39) http://bulgaria.usaid.gov/community-funds/page.html

40) http://www.usaid.gov/stories/nicaragua/cs_nc_coffee.html 
체나 주민들을 위해 실행하는 사회적 기업들의 인도주의적 지원사업들을 지원하는 방법이 있을 수 있다.

셋째, 지역개발사업의 수단으로써 현지의 사회적 기업을 육성하는 프로그램을 진행할 수 있다. 국 내에서 노동부와 같은 정부부처들이 국내에서의 고용창출과 취약계층에 대한 사회서비스 지원을 위해 사회적 기업들을 적극 육성하는 것과 같이, $\mathrm{ODA}$ 기관들이 수원국에서 사회적 기업 육성을 위 한 팩키지 프로그램을 만들어 지원하는 방법이 있을 수 있다.

넷째, 장기적으로는 공여국내에서 국제개발형 사회적 기업 창업과 사회적 기업가들의 육성을 도모 하는 방법이 있을 수 있다. ODA기관들이 시행하는 세계시민교육과 인식개선사업들을 발전시켜 공 여국내에서 국제개발형 사회적 기업가들을 육성하는 프로그램을 진행하는 한편 ODA기관의 국내외 자원을 이용하여 사회적 기업들의 창업활동과 해외진출을 지원하는 것도 한 방법이 될 것이다.

다섯째, $\mathrm{ODA}$ 기관이 직접 사회적 기업을 창업하거나 기존 사업 중의 일부를 사회적 기업에 아웃소 싱하는 방법이 있을 수 있다. 지속적인 수요가 있는 사업아이템을 자체적인 사회적 기업의 창업을 통해 해소하거나, 반대로 기관의 사업아이템을 외부의 사회적 기업에 아웃소싱하여 서로 윈윈하는 방법을 만들 수 있을 것이다.

$\mathrm{ODA}$ 가 사회적 기업과 연계되기 위해서는 넘어야할 산들이 많을 수밖에 없다. 수원국의 요청이 없 으면 임의적으로 집행하기 어려운 양자간 원조관계 속에서 현지 사회적 기업의 활동을 지원하려면 $\mathrm{ODA}$ 기관이 적극적으로 프로젝트를 발굴해나갈 필요를 가지게 한다. 또한 사회적 기업이 달성하는 비즈니스의 성과를 단기간에 측정하기도 힘들고 시장기반의 사업이므로 위험부담이 있다는 것 또한 $\mathrm{ODA}$ 기관들에게는 부담이 될 수 있다.

$\mathrm{ODA}$ 와 사회적 기업과의 만남은 $\mathrm{ODA}$ 기관들로 하여금 원조가 아닌 투자의 개념에 눈을 뜨게 하며, 영리와 비영리의 가치혼합의 문제를 새롭게 이해하게하며, 자신들의 지원방식에 사회적 기업의 활 동을 저해하는 요소가 있는 것은 아닌지 성찰하는 등 전반적으로 새로운 제휴관계를 형성하는데 있 어 변화의 필요성을 느끼게 할 것이다.

\section{2. 한국의 사회적 기업을 위한 $\mathrm{KOICA}$ 의 역할}

$\mathrm{KOICA}$ 의 사업들 중 아직까지 사회적 기업과 직접적인 연관성을 가진 사업을 찾아보기는 힘들다. 다만 KOICA가 파견한 한국해외봉사단원들 중 현지에서의 프로젝트가 사회적 기업의 맥락에서 진 행되는 경우들을 볼 수 있다. 에콰도르 갈라파고스섬의 휴까사 호텔의 개원이나 방글라데시에서의 
아리랑잼 공장 등은 고용창출과 지속가능한 소득원 확보를 위한 기업적 형태의 개발사업으로써 사 회적 기업의 한 형태라고 볼 수 있을 것이다. 또한 $\mathrm{KOICA}$ 가 시행하는 민간단체지원사업에서 국내 의 개발NGO가 시행하는 사회적 기업 관련사업이 선정되어 진행되는 경우가 있는데 2009년 한국 $\mathrm{YMCA}$ 전국연맹의 ‘동티모르 커피 공정무역 캠페인 지원사업’이 그러한 예이다. 아직까지는 KOICA 의 사회적 기업 지원이 해외봉사단원 개인의 아이디어나 역량에 기초하거나 또는 사회적 기업을 운 영하는 개발NGO들의 사업을 간접지원하는 방식에 한정되어 있다고 할 수 있는데, 앞으로 국제개 발협력의 중요한 파트너로써 사회적 기업들을 독립된 섹터로 분류하고 사회적 기업의 진흥을 통한 국제개발협력의 효율성과 확장성을 도모할 필요가 있겠다. 구체적인 방법으로 단기적으로는 다음 과 같은 지원사업들을 기획해 볼 수 있을 것이다.

첫째, $\mathrm{KOICA}$ 가 한국해외원조단체협의회를 통해서 국내의 개발NGO들을 위해 파견하는 민간단체 해외봉사단을 사회적 기업으로까지 대상을 확대할 필요가 있다. 국내의 사회적 기업들은 현장개척 과 품질관리 등 현장파트너들과 함께 해 줄 현지파견요원들이 절실히 필요하나 재정적인 문제들로 인해 적극적인 행보를 하기 힘든 실정이다. 현재는 창구가 한국해외원조단체협의회로 단일화되어 있어서 해원협에 가입요건이 되지 않는 사회적 기업들은 수요를 가지고 있음에도 불구하고 필요한 지원을 받지 못하고 있다. 민간단체해외봉사단 지원은 국내 사회적 기업들을 위해 가장 우선적으로 적용되어야 할 프로그램이라고 본다.

둘째, 국내의 국제개발형 사회적 기업 중 주류를 이루고 있는 공정무역단체들을 대상으로 지원프로 그램을 실시할 필요가 있다. 작게는 정부 차원의 사회적 기업 물품 우선구매 지원처럼 $\mathrm{KOICA}$ 가 공 정무역단체들의 물품을 우선구매해주는 지원이 가능할 것이며, 적극적으로는 공정무역단체들에게 민간단체지원사업의 일환으로 사업비를 지원해주는 방법도 필요할 것이다. 궁극적으로는 공정무역 단체들을 포함하여 ‘사회적 기업지원사업’이라는 별도의 프로그램이 만들어질 필요가 있다고 본다.

셋째, 한국해외봉사단의 교육커리큘럼에 사회적 기업과 사회적 기업가정신 또는 기업적 접근방법 등에 대한 내용을 교육과목에 포함시킬 필요가 있다. 최근 특허청과의 협력으로 한국해외봉사단의 교육커리큘럼에 지식재산을 활용한 개도국 지원에 대한 교육이 이루어진 것으로 알고 있다. ${ }^{41)}$ 현지 에서 활동하면서 상품화 가능한 아이템을 발굴하면 전문가 컨설팅을 통해 브랜딩 전략 수립 및 상 표 획득 지원이 이루어지게 하는 것인데 단원들의 마인드가 전환되어야 하고 후속의 지원체계가 정 립되어야 하는 과제가 있지만 시범적으로라도 관련 강의들이 도입될 필요가 있다고 본다.

$41)$ '지식재산을 활용한 개도국 지역개발 지원을 통해 성숙한 세계국가로'. 이강민 특허청 국제기구팀장. 2009년 5월 30 일.http://kipo.news.go.kr/gonews/branch.do?act=detailView\&datald=155351947\&sectionld=op_sec_1\&type=news\&c urrPage $=2 \&$ flComment $=1$ \&fIReply $=0$ 
넷째, '국제개발형 사회적 기업’이나 '사회적 기업을 통한 국제개발'등을 주제로 실무모임이나 연구 활동들을 지원하였으면 한다. $\mathrm{KOICA}$ 가 국제개발협력에 관심 있는 국내의 사회적 기업가들과 간담 회를 해 볼 필요가 있으며, 해외의 우수사례들을 배울 수 있는 세미나를 개최하는 것도 좋은 방법일 것이다. 또한 본격적인 연구와 보급을 위해 국제개발협력과 사회적 기업에 관한 연구용역을 실시할 필요성도 있을 것이다.

KOICA가 대상으로 하고 있는 '민간'의 범위에는 대학, 기업, NGO 등 다양한 범주가 존재하기 때 문에 사회적 기업들에 대한 지원도 의지만 있다면 가능할 것이라 생각한다. 다만 기존의 지원받는 기관들 중 기업들은 수익을 목적으로 하고 있고 개발NGO들은 서비스전달을 주요 목적으로 했다 면, 사회적 기업들은 비영리적인 목적을 가지고 있으면서도 경영적 마인드로 움직이며 상품개발, 유통망확보, 현지 창업 등 영리적인 활동도 수행할 수 있으므로 그 특성에 걸맞게 독립된 섹터로써 새롭게 지원체계를 구성해 줄 필요가 있을 것이다.

\section{V. 마치는 글}

이 글이 국내에서는 처음으로 국제개발협력과 사회적 기업을 연계해서 서술한 글이 아닐까 생각한 다. 국제개발형 사회적 기업들에 대한 연구는 이제 막 시작단계라고 보며 앞으로 많은 연구자들과 활동가들이 함께 담론을 만들어나갔으면 하는 바램이다.

아직까지는 국제개발협력과 사회적 기업이 각기 다른 분야로 독립적으로 연구되며 실행되고 있지 만 두 분야가 만나는 지점에서 빈곤퇴치와 개발의 문제에 새로운 단서가 드러나지 않을까 기대한 다. 국제개발협력에서는 새로운 마인드와 방법론을, 사회적 기업에서는 새로운 시장과 전망을 얻을 수 있을 것이다. 더불어, 날이 갈수록 늘어나고 있는 국제개발협력에 관심 있는 청년들에게 국제개 발형 사회적 기업이 하나의 통로가 될 수 있을 것이다. 기존의 국제기구나 개발NGO들로는 수많은 청년들에게 모두 기회를 제공할 수도 없으며, 이전방법들의 효용성에 대해 의문을 가진 청년들에게 제대로 된 실마리를 제공해주기도 힘들다. 그런데 국제개발협력에서의 사회적 기업의 도입은 청년 들의 유연함이 마인드의 전환으로 발전하고, 청년들의 도전정신이 창업에의 실험정신으로 승화되 어 새로운 국면을 창조할 수 있을 것으로 본다.

마지막으로 이러한 의문을 가질 수 있을 것이다. “사회적 기업은 과연 빈곤퇴치의 대안이 될 수 있 는가?” 
사회적 기업가들은 그들 존재의 유용성을 이론적으로나 학술적으로 증명하는 것에는 그리 큰 관심 이 없는 것 같다. 그들의 주요한 관심은 그들의 활동이 대안인지 아닌지를 따지는 것 보다 새롭게 포착한 시장기회를 어떻게 활용하여 사회문제를 더 잘 해결해나갈 것인가 하는 실천분야에 집중되 어 있다. 그들의 활동만큼이나 높아지는 시장점유율과 실적은 곧바로 사회적 파급력으로 이어져서 개인의 사적이익이 아닌 우리 모두를 위한 사회적 자본을 증가시키는 결과가 될 것이기 때문이다. 사업에 실패한다하더라도 사회적 기업가들은 그 경험을 바탕으로 다음번 창업을 준비하면 된다. 사 회적 기업가들은 이론이 아닌 결과로써 자신들의 존재를 증명할 기회를 가지고 있는 것이다. 만약 사회적 기업이 대안이 된다면 그것은 그들의 사업내용이 우수해서일 수도 있지만, 근본적으로는 위 험을 감수하고 실패를 겪으면서도 또다시 일어설 수 있는 기업가정신이 중요한 원인일 것이다.

사회적 기업은 새로운 접근방식으로 인해 기본적으로는 한국의 국제개발협력 전반에 새로운 관점 을 도입하고 변화를 자극하는 촉진자 역할을 할 수 있으며, 장래성으로 본다면 한국의 국제개발협 력 관련기관들 중에서도 가장 효율적이면서도 효과적으로 움직이는 유력한 조직이 될 가능성이 크 다고 본다. 따라서 한국의 $\mathrm{ODA}$ 기관들과 개발 $\mathrm{NGO}$ 들은 글로벌파트너십의 구축 과정에서 새로운 조 력자가 될 사회적 기업들에 대한 관심을 지속적으로 가지고 적극적으로 국제개발협력분야에 끌어 들이고 적용하려는 노력을 해야 하겠다. 


\section{참고문헌}

\section{1. 국내문헌}

김정희. 2009. 『공정무역, 희망무역』. 동연.

유병선. 2007.『보노보혁명』. 부키.

알렉스 스테픈. 2009.『월드체인징』. 바다출판사.

데이비드 본스타인. 2008. 『달라지는 세계』. 지식공작소.

데이비드 스즈키, 홀리 드레슬. 2006. 『굿뉴스』. 샨티.

이매진피스. 2009.『희망을 여행하라』. 소나무.

재클린 노보그라츠. 2009.『블루스웨터』. 이른아침.

존 엘킹턴, 파멜라 하티건. 2008. 『세상을 바꾼 비이성적인 사람들의 힘』. (주)에이지21. 무하마드 유누스. 2008.『가난없는 세상을 위하여』. 물푸레.

넥스터스. 2008. 『아름다운 거짓말』. 북노마드.

와타나베 나나. 2008.『미래사회를 여는 변화의 물결』. (주)에이지21.

와타나베 나나. 2007.『체인지메이커』. 넥서스BOOKS.

실벵 다르니, 마튜 르 루. 2006. 『세상을 바꾸는 대안기업가 80인』. 마고북스.

\section{2. 언론자료}

포브스코리아. “착한 일은 돈도 된다.” 2008년 11월 23일.

한겨레. “돈벌어 남주는 “착한기업”들의 성공시대”. 2009년 5월 14일.

한겨레 21. “공정무역은 아직도 배가 고프다”. 2007년 8월 23일. 674호.

한겨레 21. “이 멋진 기술”. 2009년 7월 24일. 770호.

김동훈의 '개발대안'에 관한 블로그. blog.naver.com/xtopaz

머니투데이의 사회적 기업 웹사이트 '쿨머니’. coolmoney.mt.co.kr

미국 국제개발청 홈페이지. www.usaid.gov

(유)SOPOONG의 ‘사회혁신기업메타블로그’. www.sopoong.net/bloglounge 아시안브릿지의 ‘착한여행사’ 인터넷 까페. cafe. naver.com/greentravel 자비은행의 국제개발협력전문 인터넷뉴스 ‘인포뉴스'. www.inponews.com 최신영의 '윤리적 소비'에 관한 블로그. blog. naver.com/annabach33 특허청 홈페이지. www.kipo.go.kr 
국제민주연대 www.khis.or.kr

그라민은행 www.grameen-info.org

노동부의 사회적 기업 홈페이지 www. socialenterprise.go.kr

대안기술센터 www.atcenter.org

대안적여행 기업가 아카데미 blog. tour4us. net

두레생협연합회 APNet www.apnet.or. $\mathrm{kr}$

동북아평화연대 바리의 꿈 www. baridream.co.kr

룸투리드 www.roomtoread.org

아름다운가게 아름다운세상프로젝트 world.bstore.org

아름다운가게 아름다운커피 www. beautifulcoffee.org

아쇼카재단 www.ashoka.org

어큐먼펀드 www.acumenfund.org

여행협동조합MAP map. haja.net

원월드헬스 www.oneworldhealth.org

이매진피스 www.imanagepeace.or.kr

인포뉴스 www.inponews.com

킥스타트 www.kickstart.org

페어트레이드코리아 www.ecofairtradekorea.co.kr

한국공정무역연합 www. fairtradekorea.net

한국YMCA전국연맹 피스커피 www. peacecoffee.co.kr

함께일하는재단 www.hamkke.org 